\title{
Legal Framework of European Inland Waterways and Croatian Legislation on Inland Waterways Navigation - Problems of Non-Harmonized Rules
}

\author{
Biljana Činčurak Erceg, PhD \\ Josip Juraj Strossmayer University of Osijek, \\ Faculty of Law Osijek, Republic of Croatia
}

Doi: 10.19044/esj.2018.c3p4 URL:http://dx.doi.org/10.19044/esj.2018.c3p4

\begin{abstract}
Inland waterway transport, as one of the oldest modes of transport, is still under-used in the European Union. Though it has many advantages over other modes of transport (it is environmentally friendly, cost-saving, energyefficient, safety), it also faces several significant problems. The European Union has recognized the importance of inland waterway transport and has adopted several regulations establishing a legal framework for this area of transport, and has launched some programs and projects to promote it. The Republic of Croatia has harmonized its national legislation with the European, and is also the party of the most important international agreements regulating inland waterway navigation. Despite this, inland waterway navigation continues to lag behind other modes of transport. One of the reasons may be that the existing legal framework (on international, European and national level) is still not satisfactory. Further improvements, harmonization of rules and preferably unification is needed. This paper analyses the international and European legal framework as well as the Croatian legislation on inland waterway transport and makes recommendations for further changes to the existing legislation.
\end{abstract}

Keywords: Inland waterways navigation (transport), fragmentary legal framework, the Republic of Croatia, legal regulation, harmonization of rules

\section{Introduction}

Inland waterways include rivers, lakes and canals, and inland waterway navigation (inland waterway transport) includes navigation on rivers, lakes and canals of a certain depth and width that are settled, marked and open for transport. Inland waterways may be entirely within the territory of one state or can be spread on the territory of two or more states which will result in a more complex regulation of their use. 
Inland waterway transport has extraordinary economic importance for a country that has and uses some water course. Although it is one of the oldest modes of transportation, it is usually underestimated in relation to other modes of transport, particularly in relation to road transport.

Inland waterway transport disadvantages are often referred to geographical limitations, inadequate infrastructure, relatively slow speed, inadequacy of the modern 'door-to-door' transportation conditions, less flexibility in comparison to road, rail and maritime transport. Multiple legal frameworks, rules that can overlap, failure to comply with regulations, nonharmonized rules and many decision making bodies further aggravates the aforementioned deficiencies. However, its benefits are often underestimated. Economy, safety, efficiency and environmental friendliness are the most important advantages of this mode of transport.

Despite its advantages, there is still a huge amount of capacity on the waterways that is not being exploited. According to Eurostat inland waterway transport progressed by only $17 \%$ in nearly three decades. (Eurostat b) Inland waterways transport has a $6.9 \%$ share of freight volume in the European Union, which has some $40,000 \mathrm{~km}$ of navigable waterways, but this share is considerably higher in countries with good waterway infrastructure. The main contributors to the EU inland waterways transport performance are by far Germany and the Netherlands. These two countries together accounted for more than $70 \%$ of the EU inland waterways transport performance in 2015. (Eurostat a, p. 117)

Over the last decades, it has been trying to revive inland waterway transport, especially in countries with larger and more significant waterways. The Republic of Croatia is one of the countries that has confirmed the importance of the development of this mode of transport, although the greater success of its work on the promotion of inland waterways transport is missing. The European Union has also recognised the great potential that Europe's inland waterway network has for cargo and passenger transport.

The condition for developed transport is an appropriate legal basis that will adequately regulate a certain mode of transport and which will provide its users with legal certainty and facilitate its use.

This paper analyses the international and European legal framework, as well as the Croatian legislation on inland waterway transport and makes recommendations for further research and changes to the existing legislation. For better understanding of the paper definitions of the national and international river will be given, as well as the explanation of the term 'freedom of navigation'. 


\section{European rivers - navigation and legal regulation}

Navigation on rivers in Europe is currently regulated by a variety rules passed by international institutions and bodies: specific river navigation commissions, United Nations Economic Commission for Europe (UNECE), the European Union for EU member states as well as national legislation. This situation is not satisfactory. In the following chapters an overview of the rivers, commissions, international public law rules, European legislation and private law treaties are shown. For the purpose of this paper further will be analysed some of the provisions relating to the Rhine, Danube and Sava River.

\section{National and international rivers}

Rivers, according to the common division accepted by many authors, are divided into national (internal, domestic) and international (conventional). National rivers are those whose flow runs from the source to the mouth, through the territory of only one country. (Andrassy, Bakotić, Seršić, Vukas, 2010) States independently regulate the navigation and exploitation of such rivers. The definitions of international rivers differ greatly. However, today, strictly legal, the international river is considered only rivers whose regime is regulated by an international treaty (hence the name of the conventional river). (Andrassy, Bakotić, Seršić, Vukas, 2010, p. 199.)

The definitions of international rivers contain different elements for distinguishing them from national rivers, e. g. whether is flowing through two or more states, whether is navigable, related to the sea, whether there is freedom of navigation on that river, etc., but all agree that it is essential that there is an international treaty or unilateral legal act regulating this river. It is not enough that the river has an international character in geographic, transport or economic terms. It is necessary to make a special agreement for each river that will contain the specific rules of navigation and other uses of that river. (Činčurak Erceg, 2013)

Rivers are part of the state territory through which they flow. The riparian state has full sovereignty over them and they are an integral part of the state territory. States do not have to allow navigation on rivers within their territory. However, when they allow it by unilateral legal act of the state, or when two or more states agree to permit a navigation on a river shared by each other (whether it is a border or successive river), we are talking about freedom of navigation.

According to Vitányi, freedom of navigation include following elements: freedom of traffic, free exercise of the shipping trade, freedom of fright, exemption from dues based on the sole fact of navigation, perfect equality of treatment for all beneficiaries of the right of navigation in the respect to the mentioned freedoms and exemption, and obligation of the 
riparians to maintain in good order the navigability of waterways governed by the regime of free navigation. (Vitányi, 1979)

\section{Rivers in the Europe}

In general, when speaking of rivers, in addition to autonomous inland waterway systems in Italy, Spain, Portugal, Finland, the United Kingdom, Ukraine and Russia; there are four waterway systems of significant importance for European inland navigation:

1. Rhine with its tributaries (Moselle, Neckar, Main and canals (Wesel-Datteln and Rhine-Herne)

2. The North-South corridor consists of the area around the IJsselmeera in North Holland, Meuse and Scheldt rivers, and a number of canals in Belgium, the Netherlands, northern France and the Seine River in France;

3. East-West Corridor - the main transit routes for this transit area include the Mittelland Canal, the Dortmund-Ems Canal and the Elbe River and Weser as links to the North German seaports.

4. South-East Corridor consists of the River Main, the Rhine-MainDanube Canal and the Danube River with numerous tributaries. (CRUP, 2006, p. 9)

In this context we should certainly emphasize the work of UNECE which has prepared the European Agreement on Main Inland Waterways of International Importance (AGN) of 1996. AGN identifies the network of European inland waterways and ports of international importance (E waterways and ports) and is intended to be carried out in the relevant programs of the contracting parties.

In the European Union, 21 out of 28 Member States have inland waterways, 13 of which have an interconnected waterway networks. (https://ec.europa.eu/transport/modes/inland_en) Europe's waterway network consists of approximately 37,000 kilometres of waterways. The core network with rivers and canals of international importance (Class IV and higher) is formed by more than 12,000 kilometres of interconnected waterways, 444 locks and several hundreds of inland ports and transhipment sites. The remaining network is made up by smaller waterways. (Commission Staff Working Document, SEC (2006) 34/3, p. 27)

\section{International treaties governing navigation on international rivers}

Inland waterways transport depends on the navigation regime established in a particular river, whether it is an international river or not and is there freedom of navigation or not. Rules differ from international river to international river. As was mentioned before, the European continent is intersected by numerous international rivers: the Danube, the Rhine, the Sava are just a few of them. Each of them still has different legal system governing 
freedom of navigation, thus creating different regimes for each of them. International agreements regulating navigation on the mentioned rivers are: Mannheim Convention for the Navigation of the Rhine of 1868 with additional protocols; Convention regarding the Regime of Navigation on the Danube (known as Belgrade Convention or Danube Convention) of 1948; Supplementary Protocol to the Convention regarding the Regime of Navigation on the Danube of 1998; Framework Agreement on the Sava River Basin of 2002 and Protocol on the Navigation Regime to the Framework Agreement on the Sava River Basin of 2002.

Ever since 1993, members of the Danube Commission are planning to organize a diplomatic conference on which a new convention on the regime of navigation on the Danube should be prepared. Since 2003, the Preparatory Committee for the Diplomatic Conference has intensified its work and established working groups. (Andrassy, Bakotić, Seršić, Vukas, 2010, p. 209.) The Member States intend to modernize Commission, by vesting additional powers in it and new functions, as well as to enlarge the circle of its members. (http://www.danubecommission.org/dc/en/danube-commission/) Their work is still in progress and it should certainly be speeded up.

This different treatment of each international river has resulted in different conditions in respect of the administration of the river, the transport rights (international transport, cabotage), the territorial scope, the scope of beneficiaries, the elements of free navigation, shipping regulations relating to vessel safety conditions and nautical skills, labour and tax conditions, etc. This complex situation is problematical both for decision making bodies and for the users of these waterways. The situation is further complicated by the fact that the concept of free navigation has been understood only in regard of international rivers since unless agreed otherwise (in international agreements or in the special acts) the principle of free navigation does not apply to national waterways.

The main European international rivers are managed by specially established navigation commissions entrusted with setting technical and legal standards for the navigation in their respective river basins. These are: Central Commission for Navigation on the Rhine (CCNR), the Danube Commission (DC), the International Sava River Basin Commission (ISRBC). The main difference between them is whether the regulations they make are binding or not. The resolutions of the CCNR are legally binding for its member states. The Danube Commission decisions and recommendations are not legally binding and need to be implemented into national legislation of its member states. Decisions of the Sava Commission in the field of navigation are legally binding for its member states.

From the mentioned, it can be concluded that such fragmentation of the institution, numerous different regimes and rules, although they exist for 
many years, will complicate the inland waterways transport. In the following chapters additional problems as well as certain clarifications will be given.

\section{Legal framework of the European Union - overview}

For the member states of the European Union, inland navigation is governed by the EU legislation. Legal regulation of inland waterways transport in the framework of the European Union began in 1958 when, under the auspices of the European Coal and Steel, Agreement concerning freight rates and conditions for the carriage of coal and steel on the Rhine was adopted. (Činčurak Erceg, 2013)

The European Commission encourages the use of inland waterways, and the importance of inland navigation is emphasized in White Paper: 'European transport policy for 2010: time to decide', that was published in 2001. The policy for the promotion of inland navigation in Europe is summarized in the NAIADES (Navigation And Inland Waterway Action and Development in Europe) Program (2006-2013) and the platform for its implementation - PLATINA project, launched in 2008. Both, NAIADES and PLATINA were extended, NAIADES 2 for the period 2014-2020 and PLATINA 2 for 2013 - 2016. The NAIADES 2 policy package 'Towards quality inland waterway transport' is the second European Action Programme aimed at moving more freight transport onto Europe's waterways while reducing emissions. (http://naiades.info/what-we-do/eu-transportpolicy/naiades-ii/)

Detailed analysis of the EU legal framework would exceed the scope and purpose of this paper, therefore only a list and short notes of the most important Regulations and Directives will be given. Consequently, the regulations that are essential for liberalization and transport security are:

a) Council Regulation (EEC) No. 2919/85 of 17 October 1985 laying down the conditions for access to the arrangements under the Revised Convention for the navigation of the Rhine relating to vessels belonging to the Rhine Navigation. Regulation has two goals 1. to give the opportunity that Member States which are not Parties to the Mannheim Convention have equal access to the Rhine and 2. to prevent persons or companies from non-member States of the European Union to benefit from the freedom of navigation of the Rhine by establishing in a Member State without having genuine link with that Member State.

b) Council Regulation (EEC) No. 3921/91 of 16 December 1991 laying down the conditions under which non-resident carriers may transport goods or passengers by inland waterway within a Member State. According to Article 1, carrier of goods or passengers by inland waterway may transport goods or passengers by inland waterway for hire or reward in a Member State in which they are not established (cabotage) if he fulfils these conditions: a) 
he is established in a Member State in accordance with its legislation and, where appropriate, $b$ ) he is entitled there to carry out the international transport of goods or persons by inland waterway. If he fulfils those conditions, he may temporarily carry on cabotage in the Member State concerned without having to set up a registered office or other establishment there.

c) Council Regulation (EC) No. 1356/96 of 8 July 1996 on common rules applicable to the transport of goods or passengers by inland waterway between Member States with a view to establishing freedom to provide such transport services. The Regulation applies to the transport of goods or passengers by inland waterway for journeys between EU countries and transit through them. And any operator shall be allowed to carry out these services without discrimination on grounds of nationality or place of establishment, if he meet the prescribed conditions.

d) Council Directive 87/540/EEC of 9 November 1987 on access to the occupation of carrier of goods by waterway in national and international transport and on the mutual recognition of diplomas, certificates and other evidence of formal qualifications for this occupation. It improves the coordination of the conditions for access to the occupation of carrier, encouraging achievement of the free provision of services and the effective exercise of the right of establishment.

e) Council Directive 91/672/EEC of 16 December 1991 on the reciprocal recognition of national boatmasters' certificates for the carriage of goods and passengers by inland waterway. The Directive gives classification of the national certificates listed in Annex I, into two groups: Group A for boatmasters' certificates valid for waterways of a maritime character and Group B boatmasters' certificates valid for the other waterways in the Community, with the exception of the Rhine, the Lek and the Waal. The Rhine navigation licence for boatmasters issued in accordance with the revised Convention for the Navigation of the Rhine shall be valid for all waterways in the Community.

f) Council Directive 96/50/EC of 23 July 1996 on the harmonization of the conditions for obtaining national boatmasters' certificates for the carriage of goods and passengers by inland waterway in the Community. The aim of this Directive is to harmonise the conditions for obtaining national boat masters' certificates for inland waterway navigation between the Member States in order to combat distortions of competition between carriers and to increase the safety of inland waterway navigation.

g) Council Directive 96/75/EC of 19 November 1996 on the systems of chartering and pricing in national and international inland waterway transport in the Community. It was adopted to limit the application of the 'system of chartering by rotation' and to adapt the inland waterways transport to free market conditions. The Directive states that in the national and 
international carriage of goods by inland waterway within the Community, contracts must be freely concluded between the parties concerned, and the prices negotiated freely.

h) Directive 2005/44/EC of the European Parliament and of the Council of 7 September 2005 on harmonised river information services (RIS) on inland waterways in the Community. It establishes rules on the use of harmonised river information services (RIS), which are designed to ensure the safety, efficiency and environmental friendliness of inland waterways in the EU.

i) $2006 / 87 / E C$ Directive of the European Parliament and of the Council of 12 December 2006 laying down technical requirements for inland waterway vessels and repealing Council Directive 82/714/EEC. This Directive is intended to promote European river transport by improving the technical harmonisation of vessels. It is designed to lay down a high level of safety equivalent to that for shipping on the Rhine. To achieve this, it provides for the introduction of a Community certificate for inland waterway vessels in each Member State, to be issued by the competent authorities, authorising them to operate on Community waterways, including the Rhine.

j) Directive 2009/100/EC of the European Parliament and of the Council of 16 September 2009 on reciprocal recognition of navigability licences for inland waterway vessels. If the requirements of the Directive are met, each Member State for the navigation on its national waterways recognizes the navigability licences issued by another Member State on the same basis as if it had issued those licences itself.

The above-mentioned Regulations and Directives cover the main technical, economic and legal issues of inland navigation: access to the market, pricing, technical prescriptions applicable to inland vessels, the boatmasters' certificates. What needs to be emphasized is that they apply only to EU member states and one should not forget that, because of Europe's geography, transport from one Member State to another frequently involves transit through non-EU countries. Further, a 'regulation' is a binding legislative act and must be applied in its entirety across the European Union. A 'directive' is a legislative act that sets out a goal that all EU countries must achieve, but it is up to the individual countries to create their own laws on how to reach these goals. This will also lead to different legal solutions from the member state to the member state.

International agreements regulating private law and transport of dangerous goods of inland waterway transport

The civil (private) law applicable to inland waterways transport (contract law, liability for the damage) is still mostly national in character. 
However, there are few international conventions that were created to regulate these issues.

a) Budapest Convention on the Contract for the Carriage of Goods by Inland Waterway (CMNI) of 2001 establishes uniform rules concerning contracts for the carriage of goods by inland waterway, such as rights and obligations of the Contracting Parties, transport documents, liability of the carrier, etc. The Budapest Convention entered into force on 1 April 2005, making freight transport on inland waterways finally regulated. Compared to other conventions, it has a relatively large number of parties (https://www.unece.org/trans/main/sc3/sc3_cmni_legalinst.html), which will contribute to the unification of the rules for the carriage of goods by inland waterways on the European continent.

b) From the other side, at present there is no international treaty that regulates inland waterway transport of passengers. These issues are regulated by national legislation. Inland waterway transport of passenger was also a subject of international unification. In 1976 under the auspices of UNECE, the Convention on the contract for the international carriage of passengers and luggage by inland waterway $(\mathrm{CVN})$ was adopted. The Convention failed to enter into force due to insufficient number of ratifications. It was ratified by the Russian Federation only. (http://www.unece.org/es/trans/main/sc3/legalinst_36_cvn.html) This situation is completely unacceptable. Although a large number of passengers are not transported by inland waterways, it is unbelievable that there is no international agreement governing the carriage of passengers in this mode of transport (especially if it is known that such rules exist and are in force for other modes of transport).

Let us mention here that, observing the EU legislation, there is Regulation (EU) No 1177/2010 on the rights of passengers when traveling by sea and inland waterway and amending Regulation (EC) No 2006/2004, whose objective is to ensure a high level of protection of and assistance to passengers throughout the Member States.

c) The Strasbourg Convention on the limitation of liability in inland navigation (CLNI) of 1988 has entered in force in 1997 but covers only a limited number of countries. In order to revise it, a new CLNI was adopted in 2012 but it is still not in force. (https://www.ccr-zkr.org/12050400-en.html) The new Convention of 2012 introduces an enlarged scope of application (the previous convention was restricted in its application only to the River Rhine and Mosel); introduces increased limits, particularly in respect of injury and death of passengers, and damages arising from the carriage of dangerous goods. In the European Union there is Directive 2008/68/EC of the European Parliament and of the Council of 24 September 2008 on the inland transport of dangerous goods that lays down common rules for the safe and secure 
transport of dangerous goods within and between EU countries by road, rail or inland waterway. It also covers aspects such as loading and unloading, the transfer to and from another mode of transport, as well as the stops in the course of the transport process. It extends the application of international rules to national transport of dangerous goods.

d) European Agreement concerning the International Carriage of Dangerous Goods by Inland Waterways (ADN) of 2000, entered into force in 2008 is the basic international treaty regulating the transport of dangerous goods by inland waterways. It provides a harmonized legal framework on the main aspects of the transport of dangerous goods and has been established to provide a high level of safety for international transport of dangerous goods on inland waterways, and in order to contribute to the protection of the environment.

\section{Inland waterway navigation legislation in the Republic of Croatia}

The inland waterways of the Republic of Croatia include following rivers: the Danube, Drava, Sava, Kupa and Una. According to Transport Development Strategy of the Republic of Croatia (2017 - 2030), the overall length of the current inland waterways in Croatia is $1016.80 \mathrm{~km}$ ((Ministry of the Sea, Transport and Infrastructure, 2017), of which 601.2 km ((Ministry of the Sea, Transport and Infrastructure, 2014 a, p. 40) has been integrated into the European network of inland waterways of international importance. The Danube part of the Republic of Croatia's inland waterways system forms a part of the Rhine-Danube Corridor. (Ministry of the Sea, Transport and Infrastructure, 2014 a, p. 40) Within the complete inland waterways sector in the Republic of Croatia there are two separated sub-systems with their specific characteristics: Danube's basin sub-system which encompasses the Danube's waterway as well as Drava's waterway, and the Sava basin sub-system which encompasses the waterways of the Sava, Kupa, and Una. (Ministry of the Sea, Transport and Infrastructure, 2014 a, p. 41) Ports in Osijek, Sisak, Slavonski Brod and Vukovar are international ports.

The Republic of Croatia is a party of the European Agreement on Main Inland Waterways of International Importance (AGN) so Drava River from its mouth to Osijek E 80-08, the Sava River to Sisak E 80-12 and future DanubeSava Canal from Vukovar to Šamac E 80-10 have become inland waterways of international importance.

Inland waterway transport is insufficiently developed, and this is confirmed again in the Transport Development Strategy of the Republic of Croatia (2014-2030), which states that the Croatian network of inland waterways represents a significant, but at the same time, completely unexploited part of national values of Croatia. (Ministry of the Sea, Transport and Infrastructure, 2014 a, p. 40) Inland waterways transport accounts for a 
very small share (less than 1\%) of the overall freight transport in Croatia. (Ministry of the Sea, Transport and Infrastructure, 2014 b, p. 59) Some authors stated that the reasons why Croatian inland waterway transport and ports on inland waterways are in development stagnation are much deeper than the administrative-legislative level which regulates the relations between port administrations and port operators. As key reasons, a shortage of quality infrastructural and supra-structural resources, the offer of land transport, changes in the cargo structure and the distribution of traffic flows can be highlighted. (Vojković, Olujić, Grubišić, 2010) In addition, we will also point out the problems of inadequate legislation.

Numerous domestic regulations are in force in the Republic of Croatia and Croatia is also a party to the most important international multilateral conventions as well as numerous bilateral agreements regulating inland waterway navigation (a list of regulations in force - national, European and international see for example in Činčurak Erceg, 2013; Bolanča, 2015; Bolanča, 2017). As an EU Member State it also has to apply EU laws. Such a situation in practice can lead to problems in the application of the relevant regulations. The Republic of Croatia is a party to Convention regarding the Regime of Navigation on the Danube, Supplementary Protocol to the Convention regarding the Regime of Navigation on the Danube, Framework Agreement on the Sava River Basin, Protocol on the Navigation Regime to the Framework Agreement on the Sava River Basin, Budapest Convention on the Contract for the Carriage of Goods by Inland Waterway, European Agreement concerning the International Carriage of Dangerous Goods by Inland Waterways, European Agreement on Main Inland Waterways of International Importance and a number of bilateral agreements (e. g. with Bosnia and Herzegovina, Romania, Slovakia, Serbia, Ukraine).

The main domestic sources of law relevant to these issues are: Inland Waterway Navigation and Ports Act, Strategy for Development of Inland Waterways in Republic of Croatia (2008-2018), Maritime Code, Ordinance on Inland Waterway Navigation, etc. Strategic documents related to the inland waterways and ports are the Strategy for the Development of Inland Waterway Transport in the Republic of Croatia (2008-2018) and Mid-term Plan of Development of Inland Waterways and Ports in the Republic of Croatia (20092016) which are in line with the European Commission's NAIADES Action Programme and will serve as a legal basis for a future supporting programme for the development of inland navigation.

Pursuant to the Article 1a, paragraph 1 of the Inland Waterways Navigation and Ports Act it is in accordance with regulations of the European Union: Council Regulation (EEC) No 2919/85 of 17 October 1985 laying down the conditions for access to the arrangements under the Revised Convention for the navigation of the Rhine relating to vessels belonging to the 
Rhine Navigation, Council Regulation (EEC) No 3921/91 of 16 December 1991 laying down the conditions under which non-resident carriers may transport goods or passengers by inland waterway within a Member State and Council Regulation (EC) No 1356/96 of 8 July 1996 on common rules applicable to the transport of goods or passengers by inland waterway between Member States with a view to establishing freedom to provide such transport services. By this Act, pursuant to the Article 1a, paragraph 2, following directives are transposed into Croatian legal system: Council Directive 91/672/EEC of 16 December 1991 on the reciprocal recognition of national boatmasters' certificates for the carriage of goods and passengers by inland waterway, Council Directive 96/50/EC of 23 July 1996 on the harmonization of the conditions for obtaining national boatmasters' certificates for the carriage of goods and passengers by inland waterway in the Community, Council Directive 96/75/EC of 19 November 1996 on the systems of chartering and pricing in national and international inland waterway transport in the Community, Directive 2005/44/EC of the European Parliament and of the Council of 7 September 2005 on harmonised river information services (RIS) on inland waterways in the Community, 2006/87/EC Directive of the European Parliament and of the Council of 12 December 2006 laying down technical requirements for inland waterway vessels and repealing Council Directive 82/714/EEC, Directive 2009/100/EC of the European Parliament and of the Council of 16 September 2009 on reciprocal recognition of navigability licences for inland waterway vessels.

Croatian Inland Waterways Navigation and Ports Act regulates the navigation on inland waterways of the Republic of Croatia, the safety of navigation on inland waterways, legal status, management of the inland waterways and ports, legal relations in respect of vessels, vessel registration procedures, transportation and contracting, navigation accidents, organization and operation of port authorities and official controls and other matters related to the navigation on inland waterways and inland ports (Article 1, paragraph 1). According to Article 1, paragraph 2, for matters not governed by this Law, the appropriate application of the Maritime Code is necessary. In relations that are not regulated by Inland Waterways Navigation and Ports Act, other laws and subordinate acts, customs in the field of inland navigation apply (Article 1, paragraph 3). This means that in the Republic of Croatia there are mutatis mutandis the same rules in the inland waterway navigation and in maritime transport.

Subsidiary application of the Maritime Code will lead to difficulties. Although we are talking about two types of navigation (inland waterways and maritime) they still have their own specifics. It is not unusual to apply the same regulation to inland waterway navigation and maritime transport. However, in the Republic of Croatia, such a solution is surprising because lex specialis 
(Inland Waterways Navigation and Ports Act) for inland waterway navigation exists, so it is not clear why the legislator has decided for such a solution and not to regulate complete inland waterway navigation with Inland Waterways Navigation and Ports Act. When observing contracts of carriage by inland waterways, Croatian Inland Waterways Navigation and Ports Act regulates in Article 181 that provisions of the Convention on the Contracts for the Carriage of Goods by Inland Waterways (CMNI) of 2000 applies also in the national carriage of goods by inland waterways. Inland Waterways Navigation and Ports Act does not regulate contracts of carriage of passengers by inland waterways, therefore Maritime Code will apply. The application of the Maritime Code to non-contractual relations in inland waterway navigation will be also problematic. For this reasons we recommend amendment of Inland Waterways Navigation and Ports Act and its codification modelled on the Maritime Code.

\section{Harmonization of rules in inland waterways}

Inland waterway navigation law is generally newer, unlike maritime law that has a long tradition. Originally, the substance of the inland waterway navigation law was regulated by the provisions of commercial law. Special regulations are created by the development of inland waterways transport.

It has been already pointed out that the international legal regime of navigation on international rivers is specifically established for each international river. This undoubtedly leads to differences in the regulation of the public law regime of navigation in certain international rivers. However, there is also a difference in the arrangement of the contract on the carriage of goods, or contract of carriage of passengers or other issues on certain international rivers (see Table 1). These differences greatly obstruct the development of inland waterway transport. However, the differences in the international public regulation of some international rivers are not large and make it less difficult to navigate than those resulting from various international agreements regulating contracts for the carriage of goods or passengers.

Table 1: EU Member States and their membership in UNECE, river commissions. EU Member states parties to CMNI, ADN and CLNI 1988. Note that all Member States do not have inland waterways.

\begin{tabular}{|c|c|c|c|c|c|c|c|}
\hline EU Member State & UNECE & CCNR & DC & SC & CMNI & ADN & $\begin{array}{c}\text { CLNI } \\
1988\end{array}$ \\
\hline Austria & + & & + & & & + & \\
\hline Belgium & + & + & & & + & + & \\
\hline Bulgaria & + & & + & & + & + & \\
\hline Croatia & + & & + & + & + & + & \\
\hline Cyprus & + & & & & & & \\
\hline Czech Republic & + & & & & + & & \\
\hline Denmark & + & & & & & & \\
\hline Estonia & + & & & & & + & \\
\hline
\end{tabular}




\begin{tabular}{|c|c|c|c|c|c|c|c|}
\hline Finland & + & & & & & & \\
\hline France & + & + & & & + & + & \\
\hline Germany & + & + & + & & + & + & + \\
\hline Greece & + & & & & & & \\
\hline Hungary & + & & + & & + & + & \\
\hline Ireland & + & & & & & & \\
\hline Italy & + & & & & & & \\
\hline Latvia & + & & & & & & \\
\hline Lithuania & + & & & & & & \\
\hline Luxembourg & + & & & & + & + & + \\
\hline Malta & + & & & & & & \\
\hline Netherlands & + & + & & & + & + & + \\
\hline Poland & + & & & & & + & \\
\hline Portugal & + & & & & & & \\
\hline Romania & + & & + & & + & + & \\
\hline Slovakia & + & & + & & + & + & \\
\hline Slovenia & + & & & + & & & \\
\hline Spain & + & & & & & & \\
\hline Sweden & + & & & & & & \\
\hline United Kingdom & + & & & & & & \\
\hline
\end{tabular}

Sources: CCNR Member States https://www.ccr-zkr.org/11030200-en.html, DC Member

States http://www.danubecommission.org/dc/en/danube-commission/member-states-of-the-

danube-commission/,

UNECE Member States

https://www.unece.org/oes/nutshell/member_States_representatives.html,

SC Member States https://www.savacommission.org/organ/1, Parties to the CMNI https://www.unece.org/trans/main/sc3/sc3 cmni_legalinst.html, Parties to the ADN https://treaties.un.org/Pages/ViewDetails.aspx?src=TREATY\&mtdsg_no=XI-D6\&chapter $=11 \&$ clang=_en,

Parties to the CLNI https://www.ccr-zkr.org/12050400-en.html

Namely, rules of road, rail or maritime transport often apply to inland waterway transport contracts, without taking into account that it is a special mode of transport that has its own specifics. (Činčurak Erceg, 2013; Grabovac, 2015)

As was already mentioned several international bodies, with varying degrees of geographical scope, legislative mandate and substantive coverage, constitute the institutional framework for inland navigation in the Europe (see Table 1). A large number of organizations do not contribute to harmonization of the rules since there are many different rules and regimes. In the available literature, a new international organization for inland navigation was proposed. Marin rightly points out that that would certainly contribute to the global promotion of inland navigation, but at the same time create new administrative difficulties and require a longer time to harmonize the existing framework. (Radionov, Ćapeta, Marin, Bulum, Kumpan, Popović, Savić, 2011) The same was concluded by the European Commission. In its First 
progress report on the implementation of the NAIADES Action Programme for the promotion of inland waterway transport, the European Commission does not suggest creating additional structures to the existing institutional framework. It declared that, under the current circumstances, it is preferable to base the organisational framework on the existing institutional actors, and to improve, modernise and coordinate working methods and relations wherever possible. (Communication from the Commission - First progress Report on the implementation of the NAIADES Action Programme for the promotion of inland waterway transport, Brussels, 5.12.2007, COM(2007) 770 final, 2007, p. 9)

Despite criticisms, existing organizations and institutions have made positive contributions to inland navigation. Anyway, the work of UNECE on issues of harmonization should be praised. The UNECE addresses a large number of issues related to technical and safety standards in inland navigation. Many UNECE resolutions, such as UNECE Resolution No. 24 on the European Code for Inland Waterways (CEVNI) and UNECE Resolution No. 31 on Recommendations on Minimum Requirements for the Issuance of Boatmaster's Licences in Inland Navigation with a view to their Reciprocal Recognition for International Traffic have been accepted and implemented by a large number of countries.

Despite some important and well-intended efforts, harmonization of rules is still inadequate. An explanation can be found in the fact that in some countries river transport law is integrated with maritime law, while in other countries is integrated with land transport.

The civil (private) law applicable to inland waterways transport is also not harmonised at the international level. Non-unification and legal gaps are particularly apparent on liability issues: both contractual and non-contractual. (Činčurak Erceg, 2012) This gives rise to legal uncertainty, may cause undue litigation and may raise the insurance costs of transport operations.

Although the European Union tries to harmonize transport rules, the harmonization has to cover not only EU Member States. We should not forget that transport from one Member State to another frequently involves transit through non-EU countries. Therefore the harmonization/unification of rules should be carried out at the international level, and include as many countries as possible.

\section{Conclusion}

The amount of transported goods and passengers is increasing from year to year. However, almost all of the extra traffic has been absorbed by the roads. Unfortunately, in the inland waterways, the share of the extra traffic is small. Inland waterways do not lose their traditional market but do not attract new users. If all the benefits of inland waterway transport (economy, 
efficiency, safety, most environmentally friendly of all transport modes) are taken into account, this situation must be changed. Inland waterway transport and the share of inland navigation on the market differ greatly across Europe. Some of the problems are: insufficient infrastructure due to the lack of appropriate maintenance and investment (waterways obtain a relatively small share of total infrastructure investment); relatively high cost of entering the inland navigation market; lack of information; the lack of training of logistics experts, freight forwarders, carriers, transport users; different legal systems governing freedom of navigation; numerous different other legal rules from one side, and the absence of some from the other; legal gaps and nonharmonized rules. Very often inland waterway legislation is fragmentary and the rules aplicaple ta a specific case has to be obtained by analisis of deferent sources of law.

Inland waterway transport in the European Union is currently administered under different legal regimes, namely the Mannheim, Belgrade Conventions and Framework Agreement on the Sava for navigation on Rhine, Danube and Sava river, relevant legislation of the Community and of Member States. This lack of unification can not only cause legal uncertainty but also other negative effects.

The fragmentation of the organizations which make rules for inland waterway transport and the lack of harmonized rules are the fundamental problems of inland waterway transport. In the previous chapters, a number of rules regulating inland waterway transport, including the most important international treaties, European Union legislation and Croatian national legislation, are presented.

On the example of the Republic of Croatia we have seen that several rivers (Danube, Drava, Sava, Kupa and Una) make its inland waterways. Some of them (Danube and Sava) are international rivers and have a special navigation regime on them. The provisions of the national Inland Waterway Navigation and Ports Act shall apply on other waterways. As an EU Member State it also has to apply EU laws. When applying national legislation, usually a lot of different sources of law will need to be consulted (Inland Waterway Navigation and Ports Act, Maritime Code, other acts, customs). This situation needs to be facilitated. Therefore, we recommend amendment of Inland Waterways Navigation and Ports Act and its codification modelled on the Maritime Code. The Republic of Croatia is not the only country with such tasks. It would be useful to explore and compare solutions of national laws in other European countries.

The absence of an international agreement regulating the carriage of passengers and their luggage by inland waterways is unacceptable. Although the number of passengers transporting by inland waters is relatively small, an international treaty should be made. Such treaty will contribute to the 
harmonization of this matter. However, when we talk about cargo transportation, Convention on the Contract for the Carriage of Goods by Inland Waterway (CMNI) and European Agreement concerning the International Carriage of Dangerous Goods by Inland Waterways (AND) are bright examples of international agreements that apply in inland waterway transport. With a relatively large number of States Parties, we can say that these issues are harmonized.

It can be noticed that in the last few years there have been no major new regulations as well as changes to the existing ones, as well as important actions and programs for the promotion of internal waterway transport. Given the low level of interest in the matter, one might be tempted to draw the conclusion that further harmonization in this field is not necessary. But that is not the case. Further action is necessary and urgent. Continued efforts are required to further harmonize or unify rules and regulations, update procedures and establish mechanisms that allow an efficient regulatory framework governing inland waterway transport.

\section{References:}

1. 2006/87/EC Directive of the European Parliament and of the Council of 12 December 2006 laying down technical requirements for inland waterway vessels and repealing Council Directive 82/714/EEC, OJ L 389, 30. 12. 2006, pp. 1-260.

2. Agreement concerning freight rates and conditions for the carriage of coal and steel on the Rhine, OJ 4, 1. 2. 1958, pp. 49-52.

3. Andrassy, Juraj; Bakotić, Božidar; Seršić, Maja \& Vukas, Budislav. (2010). Međunarodno pravo 1, 2. izmijenjeno izdanje. Zagreb: Školska knjiga,

4. Bolanča, Dragan. (2015). Hrvatsko plovidbeno upravno pravo. Split: Sveučilište u Splitu, Pravni fakultet.

5. Bolanča, Dragan. (2017). Prometno pravo Republike Hrvatske. Split: Sveučilište u Splitu, Pravni fakultet.

6. CCNR, Revised Convention for Rhine Navigation of 17 October 1868 as set out in the text of 20 November 1963 (Unofficial consolidated text). Retrieved from http://www.ccrzkr.org/files/conventions/convrev_e.pdf.

7. CCNR. CCNR Member States. Retrieved from https://www.ccrzkr.org/11030200-en.html.

8. CCNR. Strasbourg Convention on the limitation of liability in inland navigation. Retrieved from https://www.ccr-zkr.org/12050400en.html. 
9. Centar za razvoj unutarnje plovidbe (CRUP). (2006). Priručnik za unutarnju plovidbu u Republici Hrvatskoj. Zagreb. Retrieved from http://www.crup.hr/crup.hr/files/Prirucnik.pdf

10. Činčurak, Biljana. (2011). Analiza međunarodnopravnih odredbi o prijevozu opasnih tvari rijekama i prijedlozi za bolju ekološku zaštitu riječnog okoliša. Zbornik radova - Internacionalni univerzitet Travnik, II. Savjetovanje s međunarodnim učešćem, Travnik: Internacionalni Univerzitet Travnik, pp. 45-56.

11. Činčurak Erceg, Biljana. (2012). Deliktni statut u hrvatskom pravu plovidbe unutarnjim vodama - de lege lata i de lege ferenda. Pravni vjesnik, vol. 28, No. 3-4, pp. 89-116.

12. Činčurak Erceg, Biljana. (2013). Međunarodne rijeke - plovida $i$ zaštita riječnog okoliša. Doctoral dissertation. Zagreb. Sveučilište u Zagrebu, Pravni fakultet.

13. Commission Staff Working Document, Annex to the Communication from the Commission on the Promotion of Inland Waterway transport "NAIADES" - an Integrated European Action Programme for Inland Waterway Transport, Brussels, 17. 1. 2006, SEC (2006) 34/3.

14. Communication from the Commission, First progress report on the implementation of the NAIADES Action Programme for the promotion of inland waterway transport, Brussels, 5. 12. 2007, COM (2007) 770 final.

15. Convention regarding the regime of navigation on the Danube, Official Gazette of the Republic of Croatia - International Agreements, No. $18 / 1998$.

16. Council Directive 87/540/EEC of 9 November 1987 on access to the occupation of carrier of goods by waterway in national and international transport and on the mutual recognition of diplomas, certificates and other evidence of formal qualifications for this occupation, OJ L 322, 12. 11. 1987, pp. 20-24.

17. Council Directive 91/672/EEC of 16 December 1991 on the reciprocal recognition of national boatmasters' certificates for the carriage of goods and passengers by inland waterway, OJ L 373, 31. 12. 1991, pp. 29-32.

18. Council Directive 96/50/EC of 23 July 1996 on the harmonization of the conditions for obtaining national boatmasters' certificates for the carriage of goods and passengers by inland waterway in the Community OJ L 235, 17. 9. 1996, pp. 31-38.

19. Council Directive 96/75/EC of 19 November 1996 on the systems of chartering and pricing in national and international inland waterway transport in the Community, OJ L 304, 27. 11. 1996, pp. 12-14. 
20. Council Regulation (EC) No. 1356/96 of 8 July 1996 on common rules applicable to the transport of goods or passengers by inland waterway between Member States with a view to establishing freedom to provide such transport services, OJ L 175, 13. 7. 1996, pp. 7-8.

21. Council Regulation (EEC) No. 2919/85 of 17 October 1985 laying down the conditions for access to the arrangements under the Revised Convention for the navigation of the Rhine relating to vessels belonging to the Rhine Navigation, OJ L 280, 22. 10. 1985, pp. 4-7.

22. Council Regulation (EEC) No. 3921/91 of 16 December 1991 laying down the conditions under which non-resident carriers may transport goods or passengers by inland waterway within a Member State, OJ L 373, 31. 12. 1991, pp. 1-3.

23. DC. Member states of the Danube Commission. Retrieved from http://www.danubecommission.org/dc/en/danubecommission/member-states-of-the-danube-commission/

24. Directive 2005/44/EC of the European Parliament and of the Council of 7 September 2005 on harmonised river information services (RIS) on inland waterways in the Community, OJ L 255, 30. 9. 2005, pp. 152-159.

25. Directive 2008/68/EC of the European Parliament and of the Council of 24 September 2008 on the inland transport of dangerous goods, OJ L 260, 30. 9. 2008, pp. 13-59.

26. Directive 2009/100/EC of the European Parliament and of the Council of 16 September 2009 on reciprocal recognition of navigability licences for inland waterway vessels (Text with EEA relevance), OJ L 259, 2. 10. 2009, pp. 8-13.

27. European Agreement concerning the International Carriage of Dangerous Goods by Inland Waterways (ADN), Official Gazette of the Republic of Croatia - International Agreements, No. 13/2008, 4/2009.

28. European Agreement on Main Inland Waterways of International Importance - AGN, Official Gazette of the Republic of Croatia International Agreements, No. 16/1998.

29. European Commission. Inland waterways, What do we want to achieve?. (2017). Retrieved from https://ec.europa.eu/transport/modes/inland_en

30. Eurostat. (2016 a). Energy, transport and environment indicators, Statistical book, 2016 edition. Luxembourg.

31. Eurostat. (2016 b). Goods transport by inland waterways. Retrieved from

http://ec.europa.eu/eurostat/tgm/mapToolClosed.do?tab=map\&init=1 \&plugin $=1 \&$ language $=$ en $\&$ pcode $=$ tr $00007 \&$ toolbox $=$ legend 
32. Framework Agreement on the Sava River Basin, Official Gazette of the Republic of Croatia - International Agreements, No. 14/2003.

33. Grabovac, Ivo. (2015). Pomorska i unutarnja plovidba - povezani sustav odgovornosti u prijevozu stvari u europskim okvirima. Poredbeno pomorsko pravo, vol. 54, No. 169, pp. 237-245.

34. Mid-term Plan of Development of Inland Waterways and Ports in the Republic of Croatia (2009-2016), Retrieved from http://www.mppi.hr/UserDocsImages/srednjorocni\%20\%20plan.pdf.

35. Ministry of the Sea Transport and Infrastructure. (2014 a). Transport Development Strategy of the Republic of Croatia (2014 - 2030). Retrieved from http://www.mppi.hr/UserDocsImages/TRDEVLP\%20STRAT-M-DOC3010-14\%20FINAL\%2025-12_15.pdf.

36. Ministry of the Sea Transport and Infrastructure. (2014 b). Transport Development Strategy of the Republic of Croatia (2014 - 2030), Anex II, 2014. Retrieved from http://www.mppi.hr/UserDocsImages/TRDEVLP\%20STRAT-DOC\%20301014\%20ANNEX\%202\%20FINAL\%2025-12_15.pdf.

37. Ministry of the Sea Transport and Infrastructure. (2017). Strategija prometnog razvoja Republike Hrvatske (2017.-2030.) (Transport Development Strategy of the Republic of Croatia (2017-2030)). Retrieved from http://www.mppi.hr/UserDocsImages/MMPI\%20Strategija\%20prom etnog\%20razvoja\%20RH\%202017.-2030.-final.pdf.

38. NAIADES 2. Retrieved from http://naiades.info/what-we-do/eutransport-policy/naiades-ii/.

39. Pomorski zakonik (Maritime Code), Official Gazette of the Republic of Croatia, No. 181/2004, 76/2007, 146/2008, 61/2011, 56/2013, 26/2015.

40. Pravilnik o plovidbi unutarnjim vodama (Ordinance on Inland Waterway Navigation), Official Gazette of the Republic of Croatia, No. 138/2015.

41. Protocol on the Navigation Regime to the Framework Agreement on the Sava River Basin, Official Gazette of the Republic of Croatia International Agreements, No. 6/2004.

42. Radionov, Nikoleta; Ćapeta, Tamara; Marin, Jasenko; Bulum, Božena; Kumpan, Ana; Popović, Nikola \& Savić, Iva. (2011). Europsko prometno pravo. Zagreb: Pravni fakultet Sveučilišta u Zagrebu.

43. Regulation (EU) No 1177/2010 of the European Parliament and of the Council of 24 November 2010 concerning the rights of passengers when travelling by sea and inland waterway and amending Regulation (EC) No 2006/2004, OJ L 334, 17. 12. 2010, pp. 1-16. 
44. SC. Sava Commission. Retrieved from https://www.savacommission.org/organ/1.

45. Strategija razvitka riječnog prometa u Republici Hrvatskoj (2008. 2018.) (Strategy for Development of Inland Waterways in Republic of Croatia (2008-2018)), Official Gazette of the Republic of Croatia, No. 65/2008.

46. Supplementary protocol to the Convention regarding the regime of navigation on the Danube, Official Gazette of the Republic of Croatia - International Agreements, No. 13/1998.

47. UNECE. (2016). Member States and Member States Representatives. Retrieved from https://www.unece.org/oes/nutshell/member_States_representatives.h tml.

48. UNECE. Budapest Convention on the Contract for the Carriage of Goods by Inland Waterway (CMNI). Retrieved from https://www.unece.org/trans/main/sc3/sc3_cmni_legalinst.html.

49. UNECE. Convention on the contract for the international carriage of passengers and luggage by inland waterway $(C V N)$. Retrieved from http://www.unece.org/es/trans/main/sc3/legalinst_36_cvn.html.

50. United Nations. Status of Treaties. AND. Retrieved from https://treaties.un.org/Pages/V iewDetails.aspx?src=TREATY\&mtdsg_no=XI-D$6 \&$ chapter $=11 \&$ clang $=$ en.

51. Vitányi, Béla. (1979). The International Regime of River Navigation. Alphen aan den Rijn: Sijthoff \& Noordhoff.

52. Vojković, Goran, Olujić, Iva \& Grubišić, Neven. (2010). Lučka politika u lukama unutarnjih voda - reguacija ili deregulacija?. Zbornik radova Pravnog fakulteta u Splitu, vol. 47, No. 4, pp. 887-902.

53. White Paper: European transport policy for 2010: time to decide, COM (2001) 370 final, Brussels, 2001.

54. Zakon o plovidbi i lukama unutarnjih voda (Inland Waterway Navigation and Ports Act), Official Gazette of the Republic of Croatia, No. 109/2007, 132/2007, 51A/2013, 152/2014. 